\title{
Holisme: Die herowering van 'n ou wysheid in 'n moderne konteks
}

\author{
M J Schoeman \\ Universiteit van Pretoria
}

\begin{abstract}
Holism: Recovering an old wisdom in a modern context

The modern epoch can be described as a progressive disenchantment of the world, leaving heavy traces in the structure of society and the psychological constitution of man. The Scientific Revolution of the 17 th century and the rise of the mechanistic world view led to the destruction of the holistic, animistic tradition which viewed man as a participant in the cosmos, not as an isolated observer. Arguing that the holistic world view must be revived in some credible form before we destroy ourselves and our environment, this essay explores some possibilities for a holistic, participating consciousness appropriate to the modern era. Ecological rather than animistic, this new world view would be grounded in the real and intimate connection between man and nature.
\end{abstract}

For a life to have meaning it must conned with other things, with some things or values beyond itself. R Norick, Philosophical Explanations

In every consideration of a single fact is the suppressed presupposition of the environmental coordination requisite for its existence.

AN Whitehead, Modes of Thought

- Voordrag gelewer op 10 Augustus 1989 by geleentheid van die 1ste simposium van die Fakulteit Teologie (Ald A) en die Departement Wysbegeerte aan die Universiteit van Pretoria ter bevordering van die verhouding teologie-filosofie. 


\section{MODERNITEIT AS ONTLUISTERING VAN DIE WERELD: 'N PLEIDOOI VIR DIE HERSTEL VAN 'N 'DEELNEMENDE BEWUSSYN'}

Die lewe in 'n laat-moderne, Westerse opset dreig om volledig meegesleur te word in 'n proses van steeds sterker wordende entropie, ekonomiese en tegnologiese chaos, ekologiese rampspoed, en uiteindelike psigiese ontreddering en ontbinding. Langsamerhand het dit begin deurskemer dat die wortels van ons dilemma nie sonder meer van sosiale en ekonomiese aard is nie, en dat nòg die sosiologie nòg die ekonomie (of ook die kombinasie van al die sg sosiale wetenskappe) op sigself 'n doeltreffende verklaring daarvoor kan gee. Al duideliker dring die besef deur dat daar met ons totale wêreldbeeld iets skort, en dat die epistemologie wat hieraan ten grondslag lê, radikaal in hersiening geneem sal moet word. In die wysgerige diskoers vind ons dan ook deurgaans pogings om die hele moderne tydsgewrig, van die $16 \mathrm{de}$ eeu tot nou toe, as 'n geheel te sien, en om die metafisiese grondslae van hierdie periode te deurgrond.

Histories gesien vind ons huidige verlies van die vermoë om aan ons lewens in 'n eventueel filosofiese of religieuse sin betekenis te gee - die splitsing van feit en waarde wat die moderne tyd kenmerk - sy oorsprong in die wetenskaplike rewolusie van die $16 \mathrm{de}$ en $17 \mathrm{de}$ eeu. Hoe het dit so gekom?

Die natuurbeeld wat tot by die vooraand van die wetenskaplike rewolusie in die Weste geheers het, was dié van 'n betowerde wêreld. Natuurverskynsels is sonder uitsondering as wonderbaarlike, lewende elemente gesien (animisme), en die mens het homself in die omgewing daarvan tuis gevoel. Die kosmos was 'n plek waartoe 'n mens behoort het. 'n Bewoner van hierdie kosmos was geen vervreemde waarnemer daarvan nie, maar iemand wat regstreeks deelgeneem het aan die drama daarvan. Sy persoonlike lot het saamgehang met die lot van die heelal, en hierdie relasie het aan sy lewe betekenis gegee. Hierdie soort bewussyn - wat 'n deelnemende (partisiperende) bewussyn genoem kan word - bring 'n versmelting of identifikasie met die omgewing mee, en getuig van 'n psigiese eenheid wat nou reeds lank tot die verlede behoort. Die alchemie was nog die laaste groot samehangende uitdrukking van 'n deelnemende bewussyn in die Weste.

Die moderne periode word gekenmerk deur 'n steeds toenemende onttowering of ontluistering (Max Weber: 'Entzauberung') van die wêreld. Vanaf die 16de eeu is die aandeel van die gees steeds sterker weggedruk uit die waarneembare wêreld. Alle wetenskaplike verklaringe verwys (altans in teorie) na materie en beweging, wat resulteer in 'n meganistiese wêreldbeeld. Ontwikkelinge wat hierdie wêreldbeeld in twyfel trek - soos byvoorbeeld die kwantum-meganika of bepaalde vorme van die hedendaagse ekologiese navorsing - het nog nie werklik 'n betekenisvolle bres geslaan in die heersende denktrant nie. En hierdie trant kom basies neer op 
ontluistering, gebrek aan deelname, die handhawing van 'n streng onderskeid tussen die waarnemer en die waargenomene. Wetenskaplike bewussyn is sedert die tyd van Descartes en Newton 'n vervreemde bewussyn: daar is geen sprake van 'n ekstatiese versmelting met die natuur nie, maar volstrekte afsondering daarvan voer die botoon. Subjek en objek word teenoor mekaar gestel. Ek val nie saam met my ervaringe nie, en maak dus nie werklik deel uit van die wêreld om my heen nie. Die logiese eindpunt van hierdie wêreldbeeld is 'n gevoel van totale materialisering: alles is ' $n$ objek, 'n vervreemde 'ding' in 'n wêreld van ander eweseer betekenislose dinge. Hierdie wêreld is nie deur myself gemaak nie; dit staan totaal onverskillig teenoor my, en ek het geen egte gevoel dat ek daaraan behoort nie. Eintlik voel ek siek tot in die diepste van my siel.

Wat hou hierdie ontluistering in wanneer ons dit in meer alledaagse terme vertaal? Dit beteken dat die landskap van ons tyd die toneel geword het van 'massale administrasie en openlike geweld' (Jacoby 1975:63), 'n stand van sake wat nie slegs deur 'n handjievol intellektueles onderken word nie, maar ook deur die breë publiek. Werk word toenemend beleef as afstompend en betekenisloos, onderlinge verhoudings is oppervlakkig en kortstondig, en die politieke arena bied meesal 'n absurde skouspel. In die vakuum wat geskep is deur die verval van tradisionele waardes en bindinge, manifesteer allerlei histeriese evangeliese herlewingsbewegings, massale bekerings tot die kerk van Reverend Moon, en ons bemerk daagliks die algemene vlug in die vergetelheid waarin verdowingsmiddels, televisie en kalmeerpille voorsien. Daar is ook 'n wanhopige behoefte aan terapie, wat langsamerhand die karakter van 'n obsessie aangeneem het: ons sien hoe miljoene mense in die ontwikkelde samelewings probeer om hulle lewens, te midde van 'n allesdeurdringende gevoel van normlooshied en kulturele desintegrasie, opnuut op te bou. 'n Tyd waarin depressie en selfmoord die gewoonste saak van die wêreld geword het, kan bepaald 'n grimmige tyd genoem word.

Enkele jare gelede het Herbert Marcuse die mens van die moderne industriestaat beskryf as eendimensioneel: 'Wanneer tegniek die universele vorm van materiële produksie word', skryf hy, 'omsluit dit 'n hele kultuur; dit ontwerp 'n historiese totaliteit - 'n "wêreld"'. Daar is nie meer langer sprake van vervreemding as sodanig nie, vervolg hy, omdat daar geen 'ek' meer is wat vervreemd kan raak nie. Ons is byna almal omgekoop, ons het onsself al lank gelede uitgelewer aan die sisteem, en ons identifiseer ons nou totaal daarmee. 'Mense herken hulleself in hulle verbruiksartikels', konkludeer Marcuse; hulle het geword wat hulle besit (Marcuse 1964:9154).

Marcuse se tese van die eendimensionele mens wat volledig opgaan in die 'Gelukkige Bewussyn' van die verbruiksartikels wat hy besit, met ander woorde die 
voorstelling van die mens as geeslose konsument, is intussen weerlê. Meer resente ondersoeke (bv dié van Sennett \& Cobb 1973) het aangetoon dat die arbeider nie soseer goedere aankoop omdat hy homself met die 'American way of life' identifiseer nie, maar vanweë 'n diepgewortelde angs vir sy eie 'ek', 'n angs wat hy probeer versag met besittings. Die oormatige konsumpsiepatroon word paradoksaal genoeg gesien as 'n manier om te ontsnap aan 'n sisteem wat hom beskadig het en wat hy heimlik verag.

Om vir goed aan dié sisteem te ontsnap lyk egter na 'n onhaalbare opsie. Tegnologie en burokratiese denkmetodes dring deur tot die verste uithoeke van ons gees, en die afskerming van 'n psigiese ruimte het basies onmoontlik geword. Uitgesoekte kandidate vir bestuursposte ondergaan deesdae opleiding wat hulle leer om met oorredingskrag te kommunikeer, sosiale omgang te vergemaklik, liggaamstaal te lees, ensovoorts. Hierdie geesteskader word vervolgens verplaas na die gebied van persoonlike verhoudings. So leer ' $n$ mens byvoorbeeld hoe jy vriende opsy skuif wat moontlik in die pad sou kon staan van jou loopbaansukses, en hoe jy nuwe kennisse verwerf wat jou beroepslewe kan bevorder. Ook die huwelik en gesinslewe - of dit nou gaan oor kinderopvoeding of oor die seksuele omgang tussen die man en die vrou - word letterlik 'n onderneming, 'n kwessie van die toepassing van die juiste tegnieke om die voorgeskrewe doel te bereik en so die verlangde goedkeuring te verwerf. Maar as die etos van die tegniek en van 'management' eenmaal die sfeer van vriendskap en seksualiteit binnegedring het, is daar bykans geen redding meer moontlik nie. Die 'wydverspreide klimaat van angs en neurose' waaraan ons onderworpe is, word dan iets onvermydeliks (Camilleri 1976:31-32).

In 'n studie oor die psigopatologie van die daaglikse lewe het Laing (1965) aangetoon hoe die psige, in 'n poging om homself teen al hierdie manipulasies te beskerm, uiteenval en valse vorme van die 'self' skep. Anders as in die geval van normale (egte) verhoudings met ander persone (afgebeeld in fig 1), is daar in hierdie omstandighede selde of ooit sprake van regstreekse omgang met andere. 'n Mens is teenoor byna niemand, allermins teenoor jouself, (ge)heel. In plaas daarvan beweeg $j y$ in ' $n$ wêreld van sosiale rolle, van omgangsrituele en geraffineerde spelvorme wat jou dwing om die self te beskerm deur wat Laing 'n 'valse-selfsisteem' noem, te ontwikkel. Die self word in twee gesplits (fig 2): die 'innerlike' self distansieer homself van die omgang, en laat dit aan sy 'beliggaamde' self (wat nou as vals of dood gesien word) oor om hom met ander in te laat op 'n manier wat volkome teatraal is, terwyl die innerlike self as 'n wetenskaplike waarnemer toekyk. Iedereen, sê Laing, speel komedie, en manipuleer om te vermy of te voorkom dat hyself gemanipuleer word. Dit gaan om die beskerming van die self, maar aangesien hierdie self afgesny is van enige sinvolle vorm van kontak, verstik dit. Namate 
mense hulleself sterker van die gebeurtenisse van hulle eie lewe distansieer, word die omgewing in toenemende mate onwerklik. Die mense word daarby voortdurend geteister deur skuldgevoelens by die besef van hoe oneg hulle optree, en hoe bulle eintlik wegvlug van wat hulle in werklikheid is of sou kon wees. Hoe meer die skuldgevoel oplaai, hoe meer word gepoog on dit te onderdruk deur verdowingsmiddels, alkohol, allerlei ontspanningsvorme - trouens enigiets waardeur vermy kan word om die realiteit van die situasie onder oë te sien. Sodra die geprakseerde selfmistifikasie of die effek van die pille begin slyt, bly die mens oor met die verskrikking van sy eie verraad en die leegte van sy gemanipuleerde 'suksesse'.

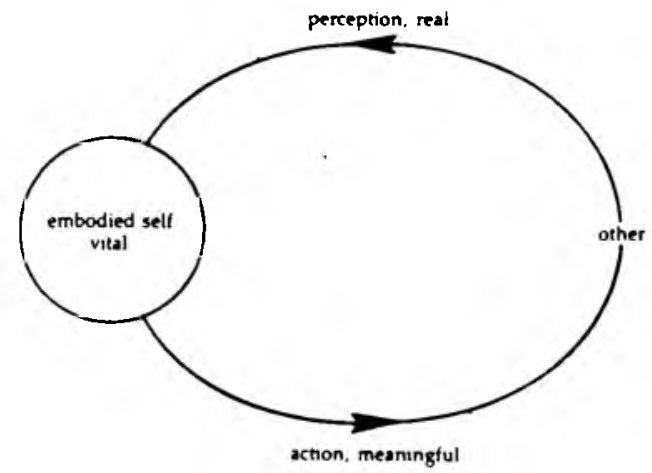

Figuur 1: Laing se skematiese voorstelling van gesonde interaksie (uit Laing 1965:81).

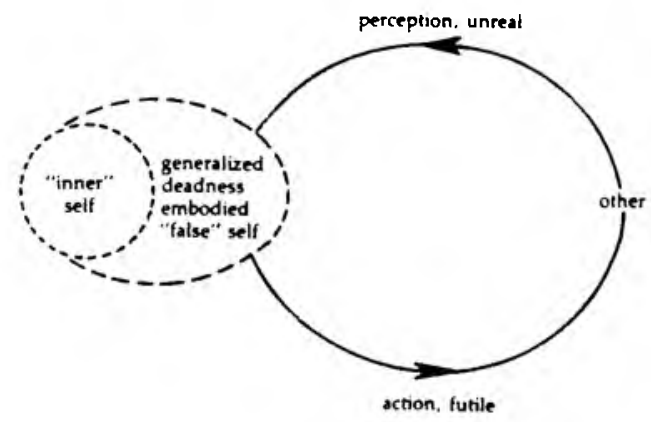

Figuur 2: Laing se skematiese voorstelling van skisoiede interaksie (uit Laing 1965:81). 
Die statistieke van hierdie situasie is skrikwekkend, maar ek kan nie hier daarop ingaan nie. Die slotsom waartoe mens kom, is soos wat 'n Amerikaanse politikoloog dit gestel het: 'The drug and the mental hospital have become the indispensable lubricating oil and reservicing factory needed to prevent the complete breakdown of the human engine' (Camilleri 1976:31-32).

Die belangrikste feit wat ons moet raaksien is dat hierdie haglike situasie nie maar sommer uit die lug geval het nie. Wat ons vandag waarneem, is die onvermydelike uitkoms van 'n eeue-oue logika wat juis in ons tyd besig is om homself uit te werk. Dit sou onsinnig wees om die wetenskap as sodanig te sien as die oorsaak van ons haglike posisie. Maar wat wél waar is, is dat die wetenskaplike (meganistiese) wêreldbeeld wat veral sedert die $17 \mathrm{de}$ eeu sy beslag gekry het, deel uitmaak of selfs die basis vorm van die moderne lewe, die verbruikersmaatskappy en die hele situasie wat hierbo beskryf is.

Daar was natuurlik ook vroeëre periodes in die geskiedenis van die mensdom waar 'n skielike toename in die snelheid waarteen veranderings plaasvind, 'n derglike radikale invloed uitgeoefen het op individuele lewens. In skynbare noodsaaklike samehang hiermee word sulke tydperke deurgaans gekenmerk deur 'n sterk toename in kranksinnigheid, of beter gestel, van wat onder kranksinnigheid verstaan word. Die mees resente plotselinge toename van depressie en neurose (of melancholie, soos wat die gemoedstoestande indertyd genoem is) het plaasgevind in die $16 \mathrm{de}$ en 17de eeu - opvallend juis aan die begin van die moderne periode, en alreeds 'n aanduiding van hoe sake sou verloop in 'n tydvak wat bekend sou word as die era van stroomversnelling, permanente rewolusie, hervorming en verandering.

Die 16de- en 17de-eeuse krisis het grootliks saamgehang met die verbrokkeling van die idee van 'n goddelike voorsienigheid en verlossing. Die krisis is uiteindelik besweer deur die opkoms van die nuwe geesteskader van die kapitalisme, en die daarmee gepaardgaande nuwe definisie van die werklikheid, wat gebaseer was op die wetenskaplike metode van eksperiment, meting en tegniese heerskappy. Die probleem is nou dat hierdie hele konstellasie van faktore - tegnologiese manipulasie van die omgewing, die daarop gebaseerde akkumulasie van kapitaal, en die idee van wêreldse verlossing wat daaraan ten grondslag lê en tegelyk daardeur gevoed word kennelik voor 'n dooiepunt te staan gekom het. Aan die einde van die 20 ste eeu blyk die moderne wetenskaplike paradigma net so moeilik houdbaar as die religieuse paradigma in die $17 \mathrm{de}$ eeu. Die fiasko van die kapitalisme, die grootskaalse geweld en terreur, die plotselinge massale betrokkenheid by ekologiese vraagstukke, die verlies aan betrokkenheid by werk, en die statistiese toename in depressie, angs en totale psigose vorm én geheel. 
In die lig van die voorgaande bespreking kan die volgende stelling gemaak word: Ontluistering is ' $n$ wesenlike eienskap van die wetenskaplike wèreldbeeld, en daarom het die moderne periode vanaf sy vroegste begin 'n bepaalde onstabiliteit in homself omgedra wat sy kanse om homself langer as 'n paar eeue staande te hou, aansienlik beperk. Vir meer as $\mathbf{9 9}$ persent van die tyd wat deur die geskiedenis van die mensdom in beslag geneem is, was die wêreld as 'betowerd' ervaar en het die mens homself as ' $n$ wesenlike onderdeel van die wèreld gesien. Die totale ommekeer van hierdie gewaarwording binne ' $n$ relatief kort tydjie van ongeveer vierhonderd jaar het 'n einde gemaak aan die kontinuïteit van die menslike ervaring en die 'integriteit' van die menslike gees. Dit het ook byna 'n einde gemaak aan die bestaan van die planeet self. Die enigste hoop, so kan daar geredeneer word, lê in 'n terugkeer van die betowering van die wêreld.

Hier raak ons aan die kern van die moderne dilemma. Ons kan nie terug na die alchemie of die animisme nie - soiets lyk in ieder geval nie juis waarskynlik nie. Maar die alternatief is die grimmige, verwetenskaplikte, totalitêr gekontroleerde wêreld van vandag. Wil ons as spesie oorleef, dan sal daar ten minste een of ander vorm van 'n holistiese of deelnemende bewussyn en 'n gepaardgaande sosio-politieke beweging moet posvat. Die verskyning van onder meer Capra se opspraakwekkende boek, The Turning Point (eerste uitgawe 1982), en die geweldige populêre aftrek wat dit gekry het, is in dié verband hoogs betekenisvol. Op die stofomslag word die tema van hierdie belangwekkende boek netjies soos volg saamgevat:

Our clinging to the mechanistic world view of Newton and Descartes has brought us perilously close to destruction. Fritjof Capra shows how these ideas are now obsolete and looks forward to a new vision more consistent with the findings of modern physics, as described in his innovative and controversial bestseller, The Tao of Physics: a holistic, systems-based approach which in this book he extends to include important areas of contemporary life - medicine, psychology, economics, political science and ecology as well as physics. We are in effect at a 'turning point' in all aspects of our culture.

(Capra 1983)

Die werk van Capra kan nie sterk genoeg aanbeveel word nie. Dit is onontbeerlike leesstof vir enigeen wat op hoogte wil kom van wat die nuwe 'holistiese' visie op die werklikheid behels, in teenstelling tot die 'meganistiese' wêreldbeeld van die afgelope vier eeue. Uiteraard kan hier nie volledig daarop ingegaan word of 'n poging 
aangewend word om 'n oorsig daarvan te gee nie. Die aandag word dus slegs gevestig op enkele aspekte wat myns insiens aandag verdien, maar voordat daarby uitgekom kan word, moet die basiese probleem (of dan keerpunt) waarvoor daar te staan gekom is, duidelik gestel word. Dit word gedoen in aansluiting by die volgende opmerking van Hill (1972:311): 'Great though the achievements of mechanical philosophy were, a dialectical element in scientific thinking, a recognition of the "irrational" (in the sense of the mechanically inexplicable) was lost when it triumphed, and is having to be painfully recovered in our own century'.

Die nadruk lê hier op die woord 'pynlik'. In die huidige tydsgewrig het kranksinnigheid met sy kenmerkende terugval na die struktuur van die premoderne denke* die vernaamste uitdrakking geword van opstand teen die heersende realiteitsprinsipe. Die opvallende toename in kranksinnigheid in ons tyd weerspieël die wanhopige behoefte aan die herstel van die deelnemende bewussyn oftewel dialektiese rede. Wie het hier gelyk? Is onderwerping van die aarde of harmonie daarmee die juiste manier om verder te gaan? Een ding lyk in elk geval seker: in die $17 \mathrm{de}$ eeu het ons die spreekwoordelike baba met die badwater weggegooi. Ons het 'n hele landskap van innerlike werklikheid verkwansel omdat dit nie ingepas het in die programme van industriële of kommersiële eksploitasie en die geïnstitusionaliseerde religie nie. Tans word in die geestelike leegte (wat die gevolg is van ons verlies aan dialektiese rede) voorsien deur allerlei twyfelagtige mistieke en okkulte bewegings - 'n gevaarlike tendens wat in feite aangemoedig is deur die ontliggaamde intellek en die klassieke geleerdheid wat die denkers en digters van die Romantiek reeds so weersinwekkend gevind het. Die moderne wetenskap en tegnologie is nie slegs op 'n vyandige houding teenoor die omgewing gefundeer nie, maar ook op die onderdrukking van die liggaam en die onbewuste. En tensy sowel die liggaam as die onbewuste herower kan word, tensy die deelnemende bewussyn herstel kan word op 'n manier wat wetenskaplik (of in ieder geval rasioneel) geloofwaardig is en nie 'n terugval in naïewe animisme inhou nie, sal menswees vir altyd sy betekenis verloor. In 1923 het die psigoloog Sándor Ferenczi 'n pleidooi gelewer vir die 'herstel van 'n animisme wat nie langer antropomorf is nie' (Brown 1970:315).

In die oorblywende gedeelte word enkele moontlikhede in dié verband verken. Daar het naamlik in ons eeu sekere ontwikkelings op intellektuele gebied plaasgevind wat as belangrike boustene gesien kan word van 'n post-Cartesiaanse (postmeganistiese, post-moderne) wêreldbeeld. Die aandag word toegespits op slegs

- Die waarneming van die wêreld in 'n hermetiese perspektief, die mobilisering van 'ooreenkomste' tussen dinge wat vir dic buitestaander geen verband met mekaar het nie - vgl die figuur Don Quichotte teenoor Sancho Panza in die verhaal van Cervantes. 
twee van hierdie ontwikkelings, naamlik die opkoms van die quantum-meganika en die sisteem-teorie. Uit die kort bespreking wat aan albei hierdie rigtings gewy word, sal hopelik duidelik word wat met die herstel van 'n deelnemende bewussyn wat 'nie langer antropomorf is nie' bedoel word. Tegelykertyd hoop ek dat die bespreking groter duidelikheid sal verskaf oor die basiese grondtrekke van wat 'n holistiese wereldbeeld genoem sou kon word.

\section{HEDENDAAGSE ONTWIKKELINGS OP INTELLEKTUELE GEBIED WAT DUI OP DIE HERSTEL VAN 'N DEELNEMENDE BEWUSSYN}

\subsection{Die quantum-meganika en sy filosofiese konsekwensies}

In die jare twintig van ons eeu vind daar in die moderne fisika iets plaas wat heeltemal onverwags die herrysenis van 'n deelnemende bewussyn aankondig. Dit is naamlik die opkoms van die quantum-meganika, waarvan die teoretiese basis 'n volledige breuk met die kennisteorie van die Westerse wetenskap inhou. Daar bestaan 'n uitgebreide literatuur oor dié onderwerp, wat nie hier uitvoerig bespreek kan word nie. Slegs 'n kort samevatting van die filosofiese konsekwensies wat uit hierdie vertakking van die fisika getrek kan word, en trouens reeds getrek is, word gegee.*

Twee begrippe is van wesenlike belang vir die kennisteorie van die klassieke (waaronder ook nog die Einsteiniaanse) fisika. Ten eerste is dit die gedagte dat die gehele werklikheid uiteindelik beskryfbaar is in terme van materie en beweging; dat die posisie van materiële deeltjies en hulle impulse (massa maal snelheid) die fundamentele werklikheid van verskynsels uitmaak. Tweedens word uitgegaan van die opvatting dat ons 'n nie-deelnemende bewussyn het: die verskynsels van die wêreld bly dieselfde, ongeag die feit dat ons aanwesig is om hulle waar te neem al dan nie; ons denkprosesse het geen enkele invloed op die harde substraat van die werklikheid nie. Die eerste van hierdie opvattings vorm die basis van 'n volstrek deterministiese siening van die werklikheid, soos wat dit veral duidelik na vore tree in die werk van die Franse wiskundige, Laplace, aan die begin van die 19de eeu. Die tweede opvatting (dat die een wat 'n eksperiment uitvoer geen deel uitmaak van sy eksperiment nie) bevestig die materialisme van die eerste opvatting, en dien ook as waarborg vir die feit dat eksperimente formeel herhaalbaar en kontroleerbaar is.

- Kyk o m die bydraes van Hoffman (1959), Heisenberg (1962), Hanson (1967), Capra (1975, 1983) en Zukav (1986), en hier te lande Van Arkel (1988). 
Die belangrikste konsekwensie van die quantum-meganika is dat daar nie so iets soos 'n onafhanklike waarnemer is nie. Een van die grondleggers van die teorie, Werner Heisenberg, het hierdie punt in 1927 in populère vorm saamgevat toe hy sy onsekerheidsbeginsel geformuleer het. Stel jou (so het hy o a gese) 'n mikroskoop voor wat sterk genoeg is om ' $n$ atoomdeeltjie, byvoorbeeld 'n elektron, mee waar te neem. Ons laat 'n lig deur die instrument val om die waarneming moontlik te maak, en ontdek vervolgens dat die lig voldoende energie besit om die elektron uit posisie te stoot. Daardie bepaalde elektron sal ons nooit kan sien nie, want die eksperiment self verander die resultate daarvan. Ons bewussyn, ons gedrag, gaan 'n deel uitmaak van die eksperiment, en daar is gevolglik geen duidelike grens tussen subjek en objek nie. Ons is sensuele deelnemers aan dieselfde wêreld wat ons poog om te beskryf.

In kort kom Heisenberg se ontdekking daarop neer dat die posisie van atomiese of subatomiese deeltjies in ruimte en tyd nooit eksak vasgestel kan word nie. En binne 'n kennisteorie wat die werklike met die materiële gelykstel, word die definisie van die woord 'werklik' plotseling problematies. " Die quantum-meganika praat van die werklikheid in terme van 'n 'waarskynlikheidsgolf' wat, soos Heisenberg dit stel, 'n nuwe variasie is van die ou begrip potentia in die Aristoteliese filosofie. 'It introduced something standing in the middle between the idea of an event and the actual event, a strange kind of physical reality just in the middle between possibility and reality.' Die ondersoekgebied van die fisika is ' $n$ 'strange kind of physical reality' waarvan die bewussyn deel uitmaak. 'What we observe', sê Heisenberg, 'is not nature in itself but nature exposed to our method of questioning' (kyk Heisenberg 1962:29, 41, 58, 81, 130, 144).

Die ironie van die quantum-meganika is dat die Cartesiaans-geinspireerde poging om die uiteindelike materiële eenheid te vind waarby die werklikheid 'verklaar' en 'subjektiwiteit' eens en vir altyd uitgesluit sou word, uitloop op ontdekkinge wat ' $n$ bespotting maak van Cartesiaanse stellings en subjektiwiteit tot die hoeksteen van 'objektiewe' kennis maak. Die reusagtige verset van wetenskaplikes teen die filosoflese konsekwensies van die quantum-meganika is heeltemal begryplik, want volledige aanvaarding van die konsekwensies beteken dat dit juis volkome onduidelik word wat 'wetenskapsbeoefening' nou eintlik inhou. Enersyds word ons terug verwys na Aristoteles se potentia. Andersyds is daar onmiskenbare ooreen-

- Let wel, die onsekerheidsbeginsel handel nie oor 'n graad van afwyking of onnoukeurigheid waarvoor daar altyd toegelaat word by eksperimentering en toetsing nie. Dit gaan hier om veel meer, naamlik dat bewussyn 'n deel uitmaak van die meting, en dat 'werklikheid' (soos wat dit vir bykans vierhonderd jaar in die Weste gedefmieer is) op sigself iets vaag en onbepaald is. 
komste met die Boeddhisme en die mistiek - iets wat eerste opgemerk is deur Joseph Needham in Science and civilization in China, en wat sedertdien deur 'n aantal skrywers nader uitgewerk is (kyk bv Capra 1975; Zukav 1986). Hoe dit ook al sy - ons kan aan een gevolgtrekking nie ontkom nie, en dit is dat die 'wêreld' nie onafhanklik van 'ons' bestaan nie. Die wêreld is nie saamgestel uit boustene van materie nie, en boonop het dit hoogs problematies geword wat materie nou eintlik presies is. Dit wil voorkom of alles met alles saamhang. Die "les van die moderne fisika is dat die subjek (waarnemende instansie) en die objek (gemete werklikheid) één naatlose geheel vorm' (Yankelovich \& Barrett 1971:203). Pantà rế, het Herakleitos gesê; alles stroom, alleen die proses is eg.

Die quantum-meganika laat ons 'n glimp sien van 'n nuwe deelnemende bewussyn wat nie sommer net 'n terugval in 'n naïewe animisme is nie. $\mathrm{Na}$ ' $\mathrm{n}$ eeuelange offisiële ontkenning van 'n deelnemende bewussyn, het die wetenskap uiteindelik die besef dat ons deelneem aan die werklikheid verdiskonteer. Histories gesien was ons altyd beperk tot ' $n$ keuse tussen twee moontlikhede: of jy neem die bestaan van 'n ontliggaamde intellek aan soos wat ons sedert $1600 \mathrm{n} \mathrm{C}$ inderdaad gedoen het of jy verval in 'n primitiewe animisme. Uit wat hierbo gesê is behoort dit duidelik te wees dat, hoe lank die hoofstroom van ons kultuur ook nog aan die eerste keuse mag bly vashou, hierdie keuse, filosofies gesien, geen toekoms het nie.

Ondertussen het 'n aantal vooraanstaande denkers, veral vanuit die chemie en die biologiese wetenskappe, die hele kwessie van deelname, van 'n dinamiese wisselwerking tussen bewussyn en werklikheid, nog 'n stap verder gevoer. * Hulle is van mening dat die intellek, of die bewuste 'gees', 'n subsisteem is van 'n groter sisteem wat ons 'Gees' (met hoofletter) sou kon noem. Hierdie geestelike werklikheid is in feite die 'strange kind of physical reality' waaroor Heisenberg dit gehad het (kyk hierbo), en wat iewers tussen moontlikheid en werklikheid hang. Bateson (1972: 461) stel dit soos volg:

The individual mind is immanent but not only in the body. It is immanent also in the pathways and messages outside the body; and there is a larger Mind of which the individual mind is only a subsystem. This larger Mind is comparable to God and is perhaps what some people mean by 'God', but it is still immanent in the total interconnected social system and planetary ecology.

\footnotetext{
- Vgl die bydraes van o m Jantsch, Prigogine \& Stengers, Lovelock, Gregory Bateson asook andere wat deur Capra (1983, hoofstuk 9), genoem word.
} 
Hiervolgens moet die Cartesiaanse ego (res cogitans) gesien word as ingeslote of omgewe deur 'n groter bewussyn of mentale sisteem waaraan hy deelneem, en net soos in 'n sel wat deel uitmaak van 'n groter orgaan, is die relasie tussen beide modaliteite osmoties. Daar kan geen vaste grens getrek word nie. Buite die mens omheen bestaan daar geen lewensgeeste binne die rotse of bome nie, maar sy relasie met die 'objekte' is ook nie een van 'n ontliggaamde intellek teenoor lewelose dinge nie. Sy relasie met die 'objekte' is liggaamlik en ekologies in die breedste sin van die woord. 'n Wetenskap wat aandag skenk aan die relasies eerder as die sogenaamde afsonderlike eenhede, sou 'n wetenskap wees wat 'n 'deelnemende waarneming' genoem word, en dit is hierdie tipe holistiese denke wat stellig die sleutel bevat tot die wetenskapsbeoefening van die toekoms. Hierdie benadering sou, in Ferenczi se woorde, as 'n 'animisme wat nie langer antropomorf is nie' aangedui kan word. Die hedendaagse pogings om 'n holistiese wetenskap te skep kan myns insiens beskou word as die onderneming en die drama van die laat 20ste eeu.

Ons staan op 'n kruispunt in die ewolusie van die Westerse bewussyn. Die een rigting handhaaf alle vooronderstellinge van die industriële rewolusie en beloof verlossing via wetenskap en tegnologie; dit gaan met ander woorde uit van die standpunt dat dieselfde paradigma wat ons in moeilikhede gebring het ons op een of ander wyse ook weer daaruit sal kan help. Voorstanders en verteenwoordigers hiervan (ook in die moderne sosialistiese state) sien 'n ekspansiewe ekonomie, toenemende verstedeliking en 'n kulturele homogeniteit op Westerse patroon as iets onvermydeliks wat tegelykertyd ook iets goeds is. Die ander rigting lei na 'n toekoms wat voorlopig nog enigsins vaag is. Die pleitbesorgers daarvan vorm 'n amorfe massa van politieke ekstremiste, ekologiste, regionale seperatiste, ekonome wat ' $n$ 'stabiele staat' (indamming) voorstaan, mistici, feministe, okkultiste en romantiese natuuraanbidders. Hulle doel is die handhawing (of herlewing) van sake soos die natuurlike milieu, streekskulture, argaïese denkwyses, organiese gemeenskapstrukture en radikaal gedesentraliseerde politieke outonomie.

Die eerste opsie lei ooglopend tot binne in 'n doodloopstraat of 'n 'Brave new world'. Die tweede lyk daarenteen dikwels na 'n naïewe poging om ons te laat omdraai en terug te keer na waar ons vandaan kom - terug te keer na die 'veiligheid' van ' $n$ verbygegane feodale tyd. Maar daar is ' $n$ wesenlike onderskeid tussen die herowering van 'n werklikheid en 'n terugkeer daarna. In sy werk Earthwalk (1975:233) maak Slater die volgende betekenisvolle opmerking: 'All the errors and follies of magic, religion and mystical traditions are outweighed by the one great wisdom they contain - the awareness of humanity's organic embeddedness in a complex and natural system'. Die herowering van hierdie wysheid staan nie gelyk 
aan die vernietiging van moderniteit nie, en tóg kan dit ons help om moderniteit te transendeer.

Die eintlike probleem is natuurlik om te ontdek hoe hierdie wysheid in 'n rype (en by ons tyd aangepaste) vorm teruggewen kan word. Dit is hier waar Capra se werk The turning point van onskatbare waarde is. Dit bied 'n uitstekende oorsig oor feitlik al die tersaaklike ontwikkelings wat oor 'n wye spektrum van kennisterreine en kultuuraktiwiteite besig is om plaas te vind. Ons het nou reeds kortliks gewys op ontwikkelings op die gebied van die fisika waaraan Capra, wat self 'n fisikus van naam is, heelwat aandag gee. In 'n slotgedeelte word die aandag op nog 'n kennisterrein gevestig, naamlik die sisteemteorie, en meer spesifiek die werk van die kultuurantropoloog/bioloog Bateson, na wie reeds hierbo verwys is. Capra verwys ook kortliks na Bateson in sy belangrike hoofstuk 9 wat handel oor die 'Systems view of life', maar myns insiens verdien hy besondere aandag omdat sy werk waarskynlik die mees volledig geformuleerde holistiese wetenskap op die huidige tydstip verteenwoordig. Bateson (oorlede 1980) is nog nie so wyd bekend nie, maar in die toekoms sal hy beslis beskou word as een van die vrugbaarste denkers van die $20 \mathrm{e}$ eeu.

2.2 Sisteemteorie: Gregory Bateson se opvattings oor mentale sisteme: Kerntemas van die (Batesoniaanse) holisme en hulle eties-maatskaplike implikasies

Die groot waarde van Bateson lê vir my in die feit dat hy die begrip 'geestelike werklikheid' (mind) uit sy tradisionele religieuse konteks losgemaak het en aangetoon het dat dit 'n 'element' is wat eie is aan die wêreld en 'n bruikbare wetenskaplike konsep. Die daaruit resulterende versmelting of sintese van feit en waarde beteken 'n enorme uitdaging aan die heersende denkwyse wat grootliks geskoei is op die digotomie (splitsing) van feit en waarde. Dit is veral hierdie sintese van feit en waarde, epistemologie en etiek, waarop ek nader wil ingaan. Maar voordat ons daarby kom wil ek eers nog 'n paar inleidende opmerkings oor Bateson se werk maak.

Die Batesoniaanse kennisteorie is in wese die uitwerk van die antwoord op slegs éen enkele vraag: wat is geestelike werklikheid? Soos wat Bateson (1972:xxv) in die voorwoord tot Steps to an ecology of mind dit vir ons beskryf, het die Westerse wetenskap probeer om 'die brug te bou na die verkeerde helfte van die ou digotomie tussen vorm en substansie'. Pleks van die geestelike werklikheid te verklaar, het die Westerse wetenskap dit weggeredeneer. Dit is moeilik om substansie (materie en beweging) as enigste verklarende uitgangspunt te neem, en dan vervolgens vorm (gees) daaruit af te lei. Volgens Bateson se denktrant is gees - sonder om dit as 'n 
religieuse prinsipe of 'n entelechie te hanteer - in alle opsigte net so reëel as materie, naamlik as 'n konkrete mentale sisteem.

Die werklikheid van hierdie mentale sisteem in Bateson se wêreldbeeld verleen aan sy epistemologie bepaalde kenmerke wat formeel ooreenkom met die alchemie en die Aristoteliese metafisika. Feit en waarde word nie van mekaar geskei nie, net so min as wat 'binne' en 'buite' afsonderlike werklikhede is. Dit gaan om kwaliteit, nie om kwantiteit nie, en die meeste verskynsels is op een of ander spesifieke manier besield of lewend. Tog is daar én groot verskil tussen Bateson se werk en al die tradisionele kennisteoretiese sisteme wat gebaseer is op die idee van 'n gewyde eenheid: 'God' kom in sy sisteem nie voor nie. Daar is geen sprake van animisme, of mana of 'oorspronklike deelname' nie. Daar bestaan wel so iets soos deelname (ons is nie afgeskei van die dinge rondom ons nie), maar dit word nie opgevat in die 'primitiewe' of premoderne sin van die woord nie.

Vir die goeie verstaan van Bateson se holistiese wêreldbeeld, kan dit nuttig wees om dit te vergelyk met die meganistiese wêreldbeeld van die moderne wetenskap. Dit word soos volg in tabel-vorm weergegee: 
Tabel 1: Vergelyking tussen die wêreldbeeld van die moderne wetenskap en dié van die Batesoniaanse holisme

\section{Wêreldbeeld van die moderne wetenskap}

- Geen relasie tussen feit en waarde. Die natuur word van buite af benader, en fenomene word los van hulle konteks ondersoek (die eksperiment). Die doel is bewuste, empiriese kontrole oor die natuur.

- Beskrywings is abstrak, wiskundig; slegs wat gemeet kan word is werklik.

- Gees staan los van die liggaam; Subjek staan los van objek.

- Lineêre tyd, oneindige vooruitgang; in beginsel kan ons alles van die werklikheid weet.

- Logika is $\partial f / \partial f$; emosies is sekondêr ơf bykomstig.

Atomisme:

- Slegs materie en beweging is werklik.

- Die geheel is niks meer as die som van die dele nie.

- Lewende sisteme is in beginsel herleibaar tot anorganiese stof; in laaste instansie is die natuur dood.
Wêreldbeeld van die Batesoniaanse holisme

- Feit en waarde onskeibaar. Die natuur word 'geopenbaar' in ons relasie daarmee, en fenomene kan alleen geken word binne hulle konteks (deelnemende waarneming). Onbewuste mentale prosesse is primêr; die doel is wysheid, skoonheid, grasie.

- Beskrywing is 'n mengsel van die abstrakte en die konkrete. Kwaliteit geniet voorrang bo kwantiteit.

* Gees/liggaam, subjek/objek is twee aspekte van dieselfde proses.

- Stroombaan-gewyse strukture (circuits), afsonderlike veranderlikes kan nie gemaksimaliseer word tot in die oneindige nie; ons kan in beginsel niks meer as 'n fraksie van die werklikheid ken nie.

- Logika is sowel/as (dialekties); die hart het 'n eksakte algoritme.

Holisme:

- Proses, vorm, relasie is primêr.

- Die geheel het eienskappe wat die dele daarvan nie besit nie.

- Lewende sisteme, of mentale sisteme (prosesse) is nie herleibaar tot hulle komponente nie; die natuur is lewend (besield). 
Vroeër is reeds betoog dat die verskrikkinge van die moderne landskap minstens gedeeltelik toe te skryf is aan die moderne wetenskaplike wêreldbeeld, met name die nadruklike splitsing tussen feit en waarde, of kennisteorie en etiek. Vir die moderne wetenskap is 'Wat kan ek weet?' en 'Hoe sal ek leef?' vrae wat absoluut niks met mekaar te make het nie. Wetenskap kan ons blykbaar geen duidelikheid gee oor wat die 'goeie lewe' sou behels nie. Natuurlik is hierdie beskeidenheid uiters verdag: 'waardevry' is self 'n waarde-oordeel, en amoraliteit is 'n bepaalde vorm van moraliteit. In die Batesoniaanse holisme is hierdie valse beskeidenheid, net soos in die voor-moderne denksisteme, gelukkig afwesig. Bateson se kennisteorie hou regstreeks 'n bepaalde etiek in, of, soos wat hy dit self stel: 'die etiek van die optima en die etiek van die maxima is totaal verskillende etiese sisteme' (Bateson 1973:248). Die slotgedeelte sal gewy word aan 'n bespreking van die etiek van die optima wat veranker lè in Bateson se holistiese wêreldbeeld."

Ek wil graag die aandag vestig op vier kerntemas in Bateson se werk wat regstreekse etiese implikasies het:

- Alle lewende sisteme is homeostaties, dit wil sê hulle is daarop gerig om bepaalde veranderlikes te optimaliseer eerder as om dit te maksimaliseer (tot 'n uiterste te voer).

- Die eenheid van 'n mentale sisteem = die eenheid van ewolusionêre voortbestaan.

- Daar is 'n fundamentele fisiologiese onderskeid tussen verslaaf raak en gewoond raak ('addiction and acclimatization').

- Die verskeidenheid van soorte is te verkies bo die homogeniteit van soorte.

In die eerste plek moet dit duidelik gestel word dat geestelike werklikheid (mind) volgens Bateson 'n kwaliteit is wat nie slegs tot die sfeer van die menslike bewussyn beperk is nie, maar dat dit inderdaad immanent is aan alle lewende sisteme (organismes èn sosiale of ekologiese sisteme). Hierdie siening het volgens Capra radikale implikasies vir die mens se verhouding met die natuurlike omgewing. 'If we separate mental phenomena from the larger systems in which they are immanent and confine them to human individuals, we will see the environment as mindless and will tend to exploit it. Our attitudes will be very different when we realize that the environment is not only alive but also mindful, like ourselves' (Capra 1983:316). Die menslike gees word binne 'n omvattende konteks (die geestelike werklikheid =

- Die volgende uiteensetting is ontleen aan Bateson (1973); Bateson (1972:122-123, 332-333, 434, 460, 483-484); Levi-Strauss (1972). 
mind) geplaas en beskou as 'n klein onderdeel (subsisteem) van 'n groter geheel. Wysheid, in Bateson se terme, is die besef dat 'n mens deel is van 'n groter stroombaan ('circuit'), asook die besef van die beperkinge van bewuste kontrole. Die deel kan die geheel nooit ken nie, maar hy kan homself, wanneer daar genoeg wysheid is, in diens van die geheel stel.

Aansluitend by hierdie opvatting van wysheid, is die opvatting dat 'n lewende (mentale) sisteem homeostaties is. Wanneer 'n afsonderlike veranderlike (gedeelte) - by die mens byvoorbeeld dié veranderlike wat normaalweg bewussyn, intellek of doelbewuste rasionaliteit genoem word - tot 'n uiterste gevoer (gemaksimaliseer) word, sal die sisteem op hol slaan en homself en sy onmiddellike omgewing vernietig. Fisiologiese sisteme het ook so 'n struktuur. Die menslike liggaam het byvoorbeeld 'n sekere hoeveelheid kalium nodig, maar ons kan nie sè 'hoe meer kalium in my liggaam hoe beter' nie. Wanneer 'n sekere punt oorskry is, kan elke chemiese element die organisme vergiftig, hoe wesenlik dit ook al is vir sy gesondheid. In biologiese terme uitgedruk: die waardesisteme van lewende eenhede hel altyd oor na optimalisering.

In die Westerse samelewing word hierdie waarheid dikwels verontagsaam. Ons is geneig om te dink dat ons onsself nooit te veel rasionele bewussyn, te veel wins of mag, te veel prestasies, en 'n te groot bruto nasionale produk kan veroorloof nie. In kibernetiese terme is so 'n manier van dink selfvernietigend en onverstandig. Bateson meen dat die kibernetiese karakter van die 'ek' so versluier is dat ons gebiologeer geraak het deur doelgerigte (tegniese) oorwegings. Kibernetika verskaf 'n belangrike insig in die aard van stabiliteit en verandering, naamlik dat verandering ' $n$ onderdeel is van die poging om stabiliteit te handhaaf. Doelgerigte gedrag, of gedrag wat iets tot die viterste wil deurvoer, beperk egter die insig in die eie stroombaan-karakter en die eie kompleksiteit, en lei tot progressiewe verandering (krisis).

Wat is 'n goeie voorbeeld van 'n optimaliserende sisteem, een wat daarin slaag om sy eie homeostatiese status te handhaaf? Om die vraag te beantwoord put Bateson uit sy kultuurantropologiese navorsing, veral sy kennis van die Bali-kultuur. Die Balinese sien in dat stabiliteit verandering en buigsaamheid vereis, en het 'n samelewingsvorm geskep wat deur Bateson paslik 'n 'stabiele staat' genoem is. Die nadruk lè op ewewig (geen veranderlike word tot 'n uiterste gevoer nie), en die etiek is 'karmies', dit wil sê dit gehoorsaam 'n wet van nie-lineêre oorsaak en gevolg, veral met betrekking tot die omgewing. Volgens Bateson word 'gebrek aan liggaamlike wysheid altyd gestraf. Wanneer jy die ekologie van 'n sisteem probeer bestry, sal jy verloor juis wanneer jy 'wen'. 
Ons tweede punt (dat die eenheid van 'n mentale sisteem identiek is met die eenheid van ewolusionêre voortbestaan) is 'n variant van die eerste punt. Volgens die sisteemteorie is die sisteem (kiberneties: stroombaan) nie die individu nie, maar die netwerk van relasies waarin hy ingebed is. ' $n$ Man is byvoorbeeld op sigself ' $n$ mentale sisteem, maar sodra hy 'n byl opraap en 'n boom begin afkap, maak hy deel uit van 'n groter mentale sisteem. Die woud rondom hom is 'n nog groter mentale sisteem, ensovoorts. In hierdie reeks van hiërargiese niveau's moet die homeostase van die grootste eenheid die kern uitmaak, soos wat die evolusie van die soorte aangetoon het. Die soort wat homself nie kan aanpas by veranderinge in sy omgewing nie, sterf uit. Daarom moet 'n 'persoon' of 'n 'organisme' gesien word as 'n mentale deelsisteem, en nie as 'n onafhanklike eenheid nie.

Die Westerse individualisme is gebaseer op 'n verwarring van die mentale deelsisteem met die mentale sisteem. Dit beskou die menslike 'gees' as die enigste geestelike werklikheid wat daar is, vry om enige veranderlike na keuse tot 'n uiterste te voer, en vry om die homeostase van die grotere eenheid te verontagsaam. Maar die Batesoniaanse etiek is juis gebaseer op relasies, op die insig dat daar 'n komplekse netwerk van paaie bestaan. Die houding van die onoorwinlike, onafhanklike 'ek' wat in die Weste so aangeprys word, is vreemd aan Bateson se denktrant. Hy beskou hierdie onafhanklikheid as 'n kunsmatige vryheid wat, indien dit eenmaal prysgegee word, 'n ander, veelomvattender soort vryheid openbaar. So stel hy ook dat Darwin se teorie van natuurlike seleksie weliswaar korrek is (die sterkste oorleef inderdaad), maar dat Darwin die eenheid van voortbestaan verkeerd bepaal het. 'Die eenheid van voortbestaan', skryf Bateson, 'sowel in die etiek as in die ewolusie, is nie die organisme of die soort nie, maar die grootste sisteem of die 'mag' waarbinne die skepsel leef. As die skepsel sy milieu vernietig, vernietig hy homself.

Mentale sisteme, vervolg hy, is inherent aan die ekosisteem, aan die totale ewolusionêre struktuur. 'Oorlewing' word dus breër opgevat om ook die sisteem van idees in 'n groter stroombaan in te sluit, en nie slegs die voortsetting van iets wat deur ' $n$ huid begrens word nie. Die ekosisteem is, kortom, rasioneel (redelik), en die reëls daarvan kan nie oortree word sonder ernstige gevolge nie. Deur sy eie voortbestaan teenoor die res van die ekosisteem te stel, en die Baconiaanse program van tegnologiese heerskappy aan te neem, het die Westerse mens binne 'n ommesientjie van drie eeue sy eie voortbestaan problematies gemaak. Die werklike eenheid van voortbestaan is nie 'n organisme of ' $n$ soort nie, maar organisme + milieu, soort + milieu. Die Joods-Christelike tradisie neig om ons as die heer van die huis te sien. Die Batesoniaanse holisme sien ons as gaste in die huis van die natuur. Bateson beskou die idee van 'n heerskappy oor die natuur as arrogant en volstrek onweten- 
skaplik. Sy eie humanisme is, net soos dié van Lévi-Strauss gebaseer op die lesse van mites, die wysheid van die sogenaamde 'primitiewe' mense, en die argaïese algoritmes van die hart. Dit is nie gerig teen die wetenskaplike intellek nie, maar slegs teen die onvermoë van die moderne wetenskap (en sy wêreldbeeld) om homself in 'n groter konteks te plaas.

Die derde punt (dié van die fundamentele fisiologiese onderskeid tussen gewenning en verslawing) beskryf wat gebeur wanneer 'n homeostatiese sisteem versteur word (kyk Bateson 1979:172-174, 178; Bateson 1972:351, 441-442, 488-490). Bateson verduidelik gewenning aan die hand van die proses van akklimatisering, soos byvoorbeeld waar 'n mens sy posisie bo seespieël verander, en daar as gevolg daarvan 'n hele reeks van komplekse fisiologiese veranderinge by hom intree. Gewenning vind plaas wanneer die sisteem afhanklik word van die voortdurende aanwesigheid van 'n faktor wat aanvanklik as 'n vreemde element beskou was. Dit is om aan te pas by 'n nuwe konteks. Dieselfde geld vir verslawing, maar hier is die faktor in feite skadelik vir die voortbestaan van die sisteem.

Die probleem is dat die grens tussen gewenning en verslawing op die lange duur taamlik vaag kan blyk te wees. Wat as 'n vernuftige vorm van aanpassing begin het, kan later tot 'n patologiese patroon ontwikkel. Die sabelvormige tande van ' $n$ luiperd kan 'n oorlewingswaarde op die kort termyn hê, maar in latere, uiteindelik kritieke situasies kan dit dalk in die pad staan van soepelheid. Die res van die sisteem pas sigself aan om die vernuwing steeds minder omkeerbaar te maak; interaksie met ander soorte skep verdere vernuwings wat die situasie weer meer kritiek maak; die soepelheid is vernietig, en ten slotte word die 'begunstigde' soort só begunstig dat hy sy eie ekologiese posisie opgee en verdwyn. By verslawing 'raak die vernuwer afhanklik van steeds hernude pogings om 'n bepaalde mate van verandering konstant te hou'. Wat op 'n bepaalde moment as 'n wins begin het, word binne 'n groter konteks 'n katastrofe.

Menslike sosiale sisteme is dikwels 'n voorbeeld van hierdie probleem, en Bateson haal die geskiedenis van DDT aan ter illustrasie. Hierdie insekdoder is in 1939 ontdek en is gesien as noodsaaklike middel om oeste te vergroot en malaria onder oorsese troepe te bestry. Dit was volgens Bateson 'n 'simptomatiese geneesniddel vir probleme wat verband hou met die bevolkingstoename'. Teen 1950 het baie wetenskaplikes reeds geweet dat DDT vir sekere diere giftig was, maar te veel ander veranderlikes het hulleself intussen weer gerangskik op 'n wyse wat dit vir ons onmoontlik gemaak het om van hierdie insekdoder af te sien. Rondom die vervaardiging daarvan het 'n reuse industrie ontstaan; die insekte waarteen die middel bedoel was het immuun geword daarteen; die diere wat hierdie insekte gevreet het, het uitgesterf; en oor die algemeen het die gebruik van DDT 'n groei van die 
wèreldbevolking moontlik gemaak. Nou het ons die punt bereik waar ons verslaaf geraak het daaraan, en die natuur probeer om dit op 'n skrikbarende manier te korrigeer. DDT kom nou voor in moedersmelk; vis is alreeds die vergiftigde draer van kwik, maar word waarskynlik tans ook die draer van DDT; drie en veertig soorte malariamuskiete is nou immuun teen die belangrikste insekdoders, en die voorkoms van malaria het in sommige lande oor die afgelope 20 jaar honderdvoudig toegeneem. Wat as 'n slim ad-hoc maatreël begin het, blyk ten slotte die probleem slegs te vererger en ons mee te sleur in 'n verslawende spiraal wat reeds ons bestaan bedreig.

Voorlopig bestaan ons reaksie op hierdie situasie bloot maar in 'n poging om die 'dosis' steeds te vermeerder. Net soos die alkoholis glo ons nog steeds dat die oplossing in ' $n$ 'rasionele beheersing' skuil. En so maak ons ons insekdoders steeds giftiger, waardeur steeds gevaarliker insekte immuun word, en die stryd gewoon al groter afmetings aanneem. Wanneer (volgens 'n 'science-fiction horrorfilm') reusagtige roofsprinkane eendag by ons kom aanklop, sal ons miskien eindelik begryp dat juis die 'rasionele beheersing' ons probleem was; maar dan sal dit al te laat wees.

Die sogenaamde energiekrisis en die hele kwessie van kernkrag is 'n ewe oortuigende voorbeeld van die verslawingspiraal. Dit (en talle ander voorbeelde) word indringend bespreek deur Capra (1983) in 'n lesenswaardige hoofstuk getitel 'The dark side of growth' (hoofstuk 8). Die slotsom waartoe 'n mens kom, is dat die moderne industriële maatskappy besig is met ' $n$ ontduiking of ontkenning van die eerste wet van die termodinamika, wat sê dat dit energie kos om energie te maak, dat jy in die fisika nooit iets vir niks kry nie. Die gebruik van energie om die probleme van die industriële maatskappy op te los, pas volledig in die geesteskader van verslawing. En ons verslawing het ongelukkig die planeet gebring by die rand van ondergang - iets wat gelukkig in ons tyd al meer en meer besef word (vgl die uitspraak van Blake dat wysheid die resultaat kan wees van 'n tot die uiterste deurgevoerde domheid!)

Ten slotte kan die probleem van verslawing op die hele Westerse lewenstyl vanaf $1600 \mathrm{n} C$ toegepas word. In die premoderne era is die rasionele (tegniese) bewussyn, met name in sy nadruk op die manipulasie van die omgewing, in toom gehou (= geoptimaliseer), omdat dit slegs éen veranderlike was in 'n sisteem wat basies georganiseer was rondom die idee van 'n sentrale harmonie. Met die koms van die wetenskaplike rewolusie is probeer om hierdie veranderlike tot 'n uiterste te voer (te maksimaliseer). Dit is uit sy sakrale konteks losgemaak, en binne enkele generasies het dit wat voorheen as verdorwe beskou is die gewoonste saak van die wèreld geword. Tans is ons volkome verslaaf aan die maksimalisering ('bigger and 
better') van veranderlikes wat ons eie sisteem vernietig. Die opkoms van die holistiese denke in ons tyd sou bes moontlik eenmaal deel kan uitmaak van die algemene proses van self-korrigerende terugkoppeling - in sisteemteoretiese (kibernetiese) terme gestel.

Die behoud van verskeidenheid (ons vierde punt), wat van wesenlike belang is vir die voortbestaan van alle biologiese sisteme, hou regstreeks verband met hierdie probleme, omdat dit beteken dat soepelheid ('flexibility') gehandhaaf word pleks van verslaafde verbruik. * Bevolkingsgenetici besef lank reeds dat die ewolusionêre eenheid nie homogeen is nie. Sonder verskeidenheid en toevallige verbindings sou geen nuwe gedragsvorme, gene of organe waarop natuurlike seleksie sou kon inwerk sig meer voordoen nie. Homogene situasies (waaronder die starheid van 'n verslawende denkpatroon) beskik nie oor die veerkrag wat nodig is vir oorlewing nie. Kwaliteite soos liefde, respek, wysheid, optimalisering, stroombaan-karakter ('circuitry') - dit alles saam mond uit in 'n etiek van verskeidenheid, en vorm uiteindelik die kern van die Batesoniaanse holisme. Tóg streef die Westerse industriële maatskappy in al sy geledinge offisieel na homogeniteit, na 'n eenheidspatroon van dink en doen, of dit nou kapitalisties of sosialisties is. In die stede verwesenlik die mens enkelsoortige ekosisteme, met name in die argitektuur, die vormgewing en die bourgeois-ideale van die 'goeie lewe'. In die landbou streef hy na 'n monokultuur: uitgestrekte landerye met slegs maar koring of mielies, pluimveebatterye wat volgens die lopende bandmodel eiers produseer. Uiteindelik word hierdie monomanie (wat teruggevoer kan word na die monomythos van die Joods-Christelike tradisie) tot alles en iedereen uitgebrei. Die Westerse humanisme, sê LéviStrauss in Tristes Tropiques, skryf uit naam van respek vir die mens één enkele lewensvorm en één enkele menstipe voor. Die vreugde om saam met iemand anders te wees, kan onder meer bestaan in die estetiese genot wat jy ervaar by die (h)erkenning van sy andersheid. Maar die reêl is dat ons die Ander haat, en eis dat hy net so moet wees soos ons: veilig, voorspelbaar en in feite 'n cliché.

In die biologiese en ekologiese wêreld beteken homogeniteit verstarring en dood. Die wêreld van die natuur vermy monotipes omdat hulle neig tot swakheid en 'n gebrek aan veerkrag wat makk dat hulle maklik uit die weg geruim word. Sisteme wat 'n gereduseerde kompleksiteit besit, toon 'n verlies van keusemoontlikhede, word onstabiel en kwesbaar. Buigsaamheid in persoonlikheidstipes en wêreldbeelde verskaf daarenteen moontlikhede vir verandering, ewolusie en werklike oorlewing. Imperialisme probeer om inheemse kulture, individuele lewens-

- Kyk Bateson, (1972:445, 451, 499); Levi-Strauss (1972), en die meeste handboeke oor genetika en ckologie vir bronne oor die volgende gedeelte. 
patrone en afwykende idees uit te roei, om sodoende 'n wêreldomvattende en homogene manier van lewe daar te stel. Variasie word as 'n bedreiging beskou. 'n Holistiese beskawing daareenteen sou variasie juis koester, en dit beskou as 'n gawe, 'n vorm van rykdom of 'n onvervreembare besitting.

Ons word vandag toenemend ingesuig in die troostelose, kleurlose wêreld van die massamens: 'n wêreld sonder egte individue, karaktervolle persoonlikhede figure wat fassineer omdat daar 'n eiesinnige kompleksiteit in hulle opgesluit lê wat moeilik ontrafelbaar is. Die populêre kultuur van ons dag lewer dan ook oorvloedige getuienis van 'n nostalgiese verlange na 'n tyd toe die gemeenskap nog baie (en 'n groot verskeidenheid) van hierdie kleurryke persoonlikhede gehad het. Die verheerliking van organiese verskeidenheid kom byvoorbeeld pragtig na vore in die boeke van die Amerikaanse skrywer John Nichols (vgl The Milagro Beanfield war wat onlangs met groot sukses verfilm is), of in Fellini se film Amarcord waarin byna elke stadsbewoner buitengewoon sonderlinge maar tegelyk heerlike eienskappe vertoon. Die lede van hierdie gemeenskappe bestry mekaar eindeloos vanweë hierdie verskille, maar dit gebeur binne die konteks van 'n intuïtiewe besef dat elkeen deel uitmaak van 'n groter ekologiese sisteem. Die stryd neem gemene trekke aan eers wanneer die sosiale ekosisteem bedreig word: in Nichols se geval deur kapitalistiese vooruitgangsidees, en by Fellini deur die fascisme. Terwyl elke persoonlikheid op sigself (en vanuit ons standpunt gesien) 'n enorme dosis irrasionaliteit openbaar, is die hele struktuur op sigself rasioneel, organies, (ge)heel. In die Westerse industriële maatskappy daarenteen word aan elkeen voorgeskryf om hom aan te pas by 'n 'rasionele', 'homogene' en tog (paradoksaal genoeg!) 'individualistiese' (in feite egoïstiese) stereotipe. Die eindresultaat is soos wat Bateson, Marcuse en talle ander dit beskryf het: dwaas en kranksinnig, 'n kolossale sisteem van vervreemding pleks van 'n ekologiese sisteem. Juis die vaartbelyning van die lewe ( $\mathrm{d} \mathrm{m} v$ moderniseringsprosesse) het, in sy vernietiging van die verskeidenheid, die menslike lewe skrikwekkend verarm.

Ten slotte wil ek die aandag vestig op die volgende uitspraak van Lévi-Strauss (1972): '[A] well-ordered humanism does not begin with itself, but puts things back in their place. It puts the world before life, life before man, and respect of others before love of self. This is the lesson that the people we call 'savages' teach us: a lesson of modesty, decency and discretion in the face of a world that preceded our species and that will survive it'.

'n Kultuur wat op hierdie grondslag berus sou 'n mens met reg 'n planetêre kultuur kon noem (in teenstelling met die mondiale massa-kultuur van die industriële samelewing). So 'n kultuur sal dromeriger en sensueler wees as ons s'n. Die innerlike psigiese landskap van drome, liggaamstaal, kuns, dans, fantasie en mite 
(almal 'analoë' ekspressievorme - Bateson) sal 'n belangrike rol speel in ons poging om die wêreld beter te begryp en te bewoon. In die geneeskunde sal daar 'n klemverskuiwing kom weg van dwelms en chemiese manipulasie na volksgeneeskuns en natuurlike geneeswyses. Daar sal voorts 'n intieme versmelting wees met ekologie en psigologie, omdat ingesien sal word dat die meeste siektes reaksies is op 'n versteurde fisiese en emosionele milieu.

'n Toekomstige holistiese kultuur sal groter verdraagsaamheid aan die dag lê jeens die vreemde en die nie-menslike, en jeens verskeidenheid in allerlei vorme. Elke gedragsvorm sal ten minste én komplement of 'skadu' hê wat om 'n legitieme uitdrukkingsvorm vra. Ruimte sal geskep word vir die skep van gedragspatrone wat nie-kumulatief en op sigself bevredigend is, in plaas van afhanklik van 'n latere vorm van beloning. Die beginsel van verskeidenheid sal die behoud van bedreigde soorte en kulture vereis, sodoende die reservoir aan genetiese moontlikhede vergroot, en die lewe stabieler, duursamer en interessanter maak.

Die sentrale motief sal nie meer wees om 'n bepaalde gebied(e) te beheers nie, maar om dit te bevry tot sy volle potensialiteit. In die politiek sal die nadruk gelê word op desentralisasie, kleinskaligheid en lokale toesig. Politieke strukture sal lokaal en outonoom wees. Die ekonomie sal dié van 'n 'stabiele staat' wees, 'n mengsel van kleinskalige sosialisme, kapitalisme en regstreekse ruilhandel. Daar sal sprake wees van 'n 'conserver society' (in plaas van die huidige 'consumer society') waarin niks onnodig verspil word nie. Die ekonomie sal 'n 'ecologica' word, 'n tak van die ekologie soos wat onder andere die ekoloë, Berg en Dasman (1978), voorostaan. Massaproduksie sal wyk voor vakmanskap, landbou-industrie voor klein, organiese en arbeidsintensiewe landbou-ondernemings, en gesentraliseerde energiebronne ( $m$ n kernenergiesentrales) voor paslike hernubare energie-moontlikhede. Die kankergewas van 'suburbia' en stedelike uitswerming (albei die teendeel van 'n egte en hegte stadslewe) sal vervang word deur 'n waaragtige stadskultuur wat eie is aan 'n bepaalde gebied, en nie 'n geforseerde weerspieëling van 'n 'internasionale' wêreld van massakommunikasie nie. Die stad sal opnuut 'n sentrum van lewenslus word, 'n agorá (Grieks vir markplein en ontmoetingsplek). Mense sal nader aan hulle werk woon, en in die algemeen sal daar so min as moontlik onderskeid bestaan tussen werk, lewe en vryetyd. (Bookchin 1973; Mumford 1938). Die tegnologie sal ons bewussyn nie langer deurdring nie, maar meer die vorm van handwerk of 'n werktuig aanneem, dinge wat binne in plaas van buite ons 'mag' sal val. In dié verband word daar gepraat van 'soft technologies' en 'technology with a human face' (Illich 1973; Schumacher 1974).

Hoe bereik ons soiets? Klink dit nie hopeloos utopies nie? Vir iemand wat meen dat slegs 'n gewelddadige rewolusie substansiële veranderings kan bewerk- 
stellig (en dit boonop in 'n kort tydsbestek van enkele dekades) het 'n planetêre kultuur uiteraard nie veel om die lyf nie. Maar wanneer ons te make het met 'n verandering van min of meer dieselfde omvang as die ineenstorting van die Romeinse Ryk (soos wat o m Roszak 1981 en Heilbroner 1976 suggereer), word ons utopiese visioen eensklaps realistieser. Feit is dat die planeet die wêreld van 'n steeds groter wordende bruto nasionale produk eenvoudig nie langer kan onderhou nie. Die industriële ekonomie begin om in te krimp. Baie is van mening dat ons sal moet 'terugkeer' na 'n stabiele-staat-ekonomie of ons nou wil of nie. Voorts word daar ook gewys op die feit dat die werknemers in die industriële ekonomie toenemend hulle werk as sinloos ervaar. Die ooglopende verval van die Protestantse arbeidsetiek is die spreekwoordelike dood in die pot vir die industriële beskawing (hieroor meer in Bell 1978).

Op politieke niveau sal die 'verval' van die huidige opset waarskynlik die vorm aanneem van die verbrokkeling van die 'nasionale' staat ten gunste van kleiner regionale eenhede. Hierdie tendens (wat ook separatisme, desentralisasie, of balkanisering genoem word) doen hom reeds op groot skaal voor. Leopold Kohr het dit reeds in 1957 (geesdriftig) voorspel in sy boek The breakdown of nations, maar die offisiële kultuur het dit soos die dood verswyg. Eers in 1977 het 200 Europese deskundiges in die boek Europe 2000 die opstand van 'n regionale periferie as 'n hoogs waarskynlike ontwikkeling in vooruitsig gestel vir die afsienbare toekoms (P Hall 1977). Sterk separatistiese bewegings bestaan nou wêreldwyd - in Spanje (die Baske), Skotland, Corsica, lerland, die VSA (Noordelike Kalifornië, Michigan, Idaho) en sedert onlangs in die Sowjetunie en Joegoslawië. Oor die algemeen is, so skryf Peter Hall (1977:167) (redakteur van Europe 2000) 'wat vroeër separatisme genoem is en nou deurgaans regionalisme heet ... miskien wel die sterkste politieke stukrag wat tans werksaam is: Dit is die vernaamste oorsaak van die sogenaamde outoriteitskrisis en die verswakking van die gesentraliseerde kontrole'.

Die holistiese samelewing (planetêre kultuur) ontspring dus aan 'n groot verskeidenheid van bronne wat dwarsdeur die tradisionele politieke 'links-regs'verdeling heensny. Feminisme, ekologie, die benadrukking van etniese outentisiteit, religieuse vernuwing, wat in politieke opsig skynbaar nie veel in gemeen het nie, beweeg wellig na een en dieselfde doel. Hierdie holistiese bewegings verteenwoordig geen bepaalde sosiale klas(se) nie, want oor die algemeen verteenwoordig hulle die onderdrukte 'skaduwees' van die industriële beskawing: die vroulike, die wildernis, die liggaam, die kreatiewe 'hoof en hart', die okkulte, en die volkere van die nie-stedelike, regionale periferieë van Europa en Noord-Amerika - gebiede wat hullself nog nie aan die industriële sentrum uitverkoop het nie en dit ook nooit sal 
doen nie. As daar iets gemeenskapliks is aan die elemente van hierdie 'teenkultuur', dan is dit die opvatting van 'herstel'. Hulle doel is die herstel van ons liggaam, ons gesindheid, ons seksualiteit, ons natuurlike omgewing, ons archaiese tradisies, ons onbewuste, ons geworteldheid in die aarde, ons gevoel van gemeenskap en verbondenheid met mekaar. Hulle bepleit nie slegs 'n program van 'geen groei' oftewel 'indamming' van die industrie nie, maar ook die regstreekse poging om iets te herwin van 'n verlede wat ons in die laaste vier eeue verloor het. Hulle wil terug om vooruit te kom. Kortom: Hulle beliggaam die onderneming om ons toekoms te herower.

\section{Literatuurverwysings}

Bateson, G 1972. Steps to an ecology of mind. New York: Balantine.

-. 1973. A conversation with Gregory Bateson, in Thayer, L (ed), Communication:

Ethical and moral issues. London: Gordon \& Breach.

--- 1979. Mind and nature: $A$ necessary unity. New York: Dutton.

Bell, D 1978. The cultural contradictions of capitalism. New York: Basic Books.

Berg, P 1978. Reinhabitating a separate country. San Francisco: Planet Drum Books. Bookchin, M 1973. The limits of the city. New York: Harper \& Row.

Brown, N O [1959] 1970. Life against death. Middeltown: Wesleyan University Press.

Camilleri, J 1976. Civilization in crisis. Cambridge: Cambridge University Press.

Capra, F 1975. The Tao of Physics. Berkeley: Shambhala.

-.. 1983. The turning point: Science, society and the rising culture. London: Flamingo. (Fontana Paperbacks.)

Hall, D L 1982. Eros and irony. Albany: SUNY Press.

Hall, P (ed) 1977. Europe 2000. London: Duckworth.

Hanson, N R 1967. Quantum mechanics, philosophical implications of, in Edwards, P (ed), The encyclopedia of Philosophy, 7, 44. New York: MacMillan.

Heilbroner, R 1976. Business civilization in decline. New York: Norton.

Heisenberg, W 1962. Physics and Philosophy. New York: Harper Torchbooks.

Henderson, H 1978. Creating alternative futures. New York: Berkeley.

Hill, C 1972. The world turned upside down. New York: Viking Press.

Hoffman, B 1959. The strange story of the quantum. Harmondsworth: Penguin.

Illich, I 1973. Tools for conviviality. New York: Harper \& Row.

Jacoby, R 1975. Social amnesia Boston: Beacon.

Kohr, L [1953] 1975. The breakdown of nations. New York: Dutton.

Laing, R D 1965. The divided self. Harmondsworth: Penguin. 
Lemaire, T 1976. Over de waarde van kulturen: Een inleiding in de kultuurfilosofie. Baarn: Amboboeken.

Lévi-Strauss, C 1972. Interview with Lévi-Strauss. Psychology Today, May 1972, p80.

Marcuse, H 1964. One-dimensional man. Boston: Beacon.

Merchant, C 1980. The death of nature. New York: Harper \& Row.

Mouton, J Van Aarde, A G \& Vorster, W S (eds) 1988. Paradigms and progress in theology. Pretoria: HSRC. (HSRC Studies in Research Methodology 5.)

Mumford, L 1938. The limits of the city. New York: Harper \& Row.

Polanyi, M 1962. Personal knowledge. Chicago: University of Chicago Press.

Rossman, M 1979. New age blues. New York: Dutton.

Roszak, T 1970. The making of a counter culture. London: Faber \& Faber.

-- 1981. Person/planet. London: Granada.

Schumacher, E F 1974. Small is beautiful. London: Abacus.

Senett, R \& Cobb, J 1973. The hidden injuries of class. New York: Vintage Books.

Slater, P 1975. Earthwalk. New York: Bantam.

Van Aarde, A G 1988. Historical criticism and holism: Heading toward a new paradigm?, in Mouton, Van Aarde, \& Vorster, 1988:49-64.

Van Arkel, J T de Jongh 1988. Theology beyond Newton: A quantum leap, in Mouton, Van Aarde, \& Vorster 1988:223-238.

Yankelovich, D \& Barrett, W 1971. Ego and instinct. New York: Vintage Books.

Zijderveld, A C 1972. The abstract society: A cultural analysis of our time. Harmondsworth: Penguin.

Zukav, G 1986. The dancing Wu Li masters: An overview of the new physics. New York: Bantam. 